\section{The Florida Series of Hybrid Amaryllis: Five New Hippeastrum Cultivars}

\author{
Alan W. Meerow ${ }^{1}$ \\ USDA-ARS-SHRS, National Germplasm Repository, 13601 Old Cutler Road, \\ Miami, FL 33158
}

Additional index words. floriculture, flower bulb, geophyte, herbaceous perennial, Hippeastrum, hybrids, ornamentals

Hippeastrum Herbert, amaryllis, has yielded popular large-flowered hybrids over a 200 -year breeding history with The Netherlands and South Africa currently dominating the market (Meerow, 2009). The U.S. Department of Agriculture breeding program, with goals of developing cultivars with heat resistance and novel floral phenotypes, has been ongoing for nearly 15 years. In this article, we announce the release and availability for license of five hybrid cultivars as the Florida series of hybrid amaryllis.

Hippeastrum 'Boca'PPAF, 'Jax' 'Miami'PPAF, 'Orlando'PPAF, and 'Tampa'PPAF' are diploid ('Jax', $2 n=22$ ), triploid ('Boca', $2 n=33$ ), or tetraploid and tetraploid-derived aneuploid ('Miami', 'Orlando', 'Tampa'; $2 n=$ 43 , 44) hybrids (Figs. 1-3). Each cultivar is suitable for forcing as flowering plants and responds successfully to the protocols summarized by Okubo (1993). The cultivars exhibit novel floral coloration patterns and resistance to red scorch [Stagonospora curtisii (Berk.) Sacc.].

\section{Origin}

These cultivars originated from a breeding program initiated in 1999 (Meerow, 2009), which began with a primary $F_{1}$ hybrid between H. ambiguum Herb. ex Hook. and H. papilio (Rav.) Van Scheepen (Table 1). Secondary $F_{1}$ interspecific crosses used in the breeding program were $H$. ambiguum $\times H$. brasilianum and $H$. lapacense (Card.) Van Scheepen $\times$ H. papilio (Table 1). All species germplasm are in the author's living research collection and were received originally from the late Fred Meyer and David Bell. Diploids were then crossed with older, commercial tetraploid cultivars in hopes of obtaining triploid or tetraploid progeny exhibiting the gigas effects of polyploidy (Bell, 1973a, 1973b, 1977) but retaining some of the unusual floral characteristics of the diploid parents.

\section{Descriptions}

Color descriptions are based on evaluations with a Minolta CR-400 colorimeter at

Received for publication 28 Apr. 2014. Accepted for publication 1 July 2014.

${ }^{1}$ To whom reprint requests should be addressed; e-mail alan.meerow@ars.usda.gov.
CIE D65/2 $2^{\circ}$ illumination/viewer conditions. The color parameters correspond to the uniform color space CIELAB, derived from Gonnet $(1993,1998)$. Two color coordinates, $a^{*}$ and $b^{*}$, as well as a psychometric index of lightness, $\mathrm{L}^{*}$, are defined. The $\mathrm{L}^{*}$ is a measurement of luminosity, i.e., the equivalence of each color on the gray scale ranging from 0 (black) to 100 (white). The a* takes positive values $(0$ to +60$)$ for reddish colors and negative values $(0$ to -60$)$ for the greenish ones, whereas the $b^{*}$ takes positive values $(0$ to +60$)$ for yellowish colors and negative values $(0$ to -60$)$ for the bluish ones. This is a much more precise and repeatable analysis of color than obtained by using color charts (Ayala-Silva et al., 2005; Ayala-Silva and Meerow, 2006; Meerow and Ayala-Silva, 2008). The colorimeter takes three consecutive measurements of each sample, which was repeated three times; thus, each set of color coordinates obtained are means of nine measurements. Where a reasonably close match could be discerned, the Royal Horticultural Society Color Chart (RHS; Royal Horticultural Society, 1995) is also referenced.

Ploidy of the cultivars was determined from leaf tissue samples with a Partec CyFlow Ploidy analyzer (Partec $\mathrm{GmbH}$, Münster, Germany) using the Precise P protocol according to the manufacturer's directions. Ten samples were assayed for each cultivar. The traces were visualized using the program WinMDI Version 2.8 (Trotter, 2004). Mitotic metaphase chromosomes of three cultivars were prepared from root tips collected in deionized water, treated for $1.5 \mathrm{~h}$ with nitrous oxide, fixed in glacial acetic acid for $3 \mathrm{~h}$, then stored in $70 \% \mathrm{EtOH}$ until staining with 4',6-diamidino-2-phenylindole.

'Boca'. 'Boca' (Figs. 1A-B and 2A-B) originated as a cross made by the inventor in purchased from commercial sources.
2001 as part of a breeding program in Miami, FL (Table 1). First flowering was in Spring 2004 at 3 years of age. Bulbs are 5 to $6 \mathrm{~cm}$ in diameter (18 to $19 \mathrm{~cm}$ circumference) at first flowering, maturing to 8 to $9 \mathrm{~cm}(\approx 28 \mathrm{~cm}$ circumference), producing one to two offset bulbs annually. Leaves are lorate with obtuse apices and entire margins, four to six per bulb, increasing to 10 to 12 late in the season, 44 to $71 \mathrm{~cm}$ long, and 3.5 to $5.5 \mathrm{~cm}$ wide. Coloration of the upper surface of the young foliage is RHS yellow-green 144A and the lower surface is RHS yellow-green 144B. The upper surface of the mature foliage is colored $\mathrm{L}^{*}(\mathrm{C})=42.72, \mathrm{a}^{*}(\mathrm{C})=-15.77, \mathrm{~b} *(\mathrm{C})=$ 23.89 ; the lower surface is $L^{*}(C)=49.99$, $\mathrm{a}^{*}(\mathrm{C})=-16.03, \mathrm{~b} *(\mathrm{C})=26.77$. Scapes are 44 to $56 \mathrm{~cm}$ tall, hollow, $\approx 1.5 \mathrm{~cm}$ in diameter, two to three per bulb, each bearing four (rarely three) flowers per scape; pedicels are 2 to $3 \mathrm{~cm}$ long. The perianth has a slight "butterfly"-like shape (most likely the influence of $H$. papilio) and is 13 to $14 \mathrm{~cm}$ long, 14 to $15 \mathrm{~cm}$ wide laterally, 16 to $18 \mathrm{~cm}$ dorsal-ventrally. The six tepals are of medium texture. Outer tepals are broadly ovate, 12.5 to $13 \mathrm{~cm}$ long, and 7 to $7.5 \mathrm{~cm}$ wide at their broadest, densely striated RHS redpurple 57A, especially the upper, with darker markings at the throat (Table 2), and faint RHS white $155 \mathrm{D}$ keels; margins are irregularly RHS white $155 \mathrm{D}$. Tepal outer surfaces are more lightly striated with infusions of RHS yellow-green 149B and RHS grayed red $178 \mathrm{~B}$ along the keels. The inner tepals are ovate, the ventral tepal narrower than the laterals, 12 to $12.5 \mathrm{~cm}$ long, and the inner laterals 6 to $7 \mathrm{~cm}$ wide; the ventral inner is $\approx 5 \mathrm{~cm}$ wide. They are colored as per the outer whorl but dark markings at the throat more pronounced on the laterals and have irregular RHS white $155 \mathrm{D}$ margins. The throat is green with a short paraperigone of lacinate fimbrae. The six stamens are 10 to $11.2 \mathrm{~cm}$ long, concolorous with the perianth for most of their length, and RHS yellow-green 149B in the proximal $1.5 \mathrm{~cm}$; anthers are elliptic, $\approx 7 \mathrm{~mm}$ long, RHS white $155 \mathrm{D}$; pollen is RHS yellow $8 \mathrm{C}$. The style is 13 to $14 \mathrm{~cm}$ and colored similarly to the staminal filaments for most of its length, RHS yellow-green 149B in the proximal $2 \mathrm{~cm}$. The trifid stigma is $\approx 7 \mathrm{~mm}$ wide, colored RHS white $155 \mathrm{D}$. Ovary shape is ellipsoid, 22 to $34 \mathrm{~mm}$ long, 8 to $11.5 \mathrm{~mm}$ wide, RHS green 141C; $2 n=33$ (Fig. 4A).

'Jax'. 'Jax' (Figs. 1C-D and 2C-D) originated as a cross made by the inventor in 2001 as part of a breeding program in Miami, FL (Table 1). First flowering was in Spring 2003

Table 1. Pedigrees of Hippeastrum 'Boca', 'Jax', 'Miami', 'Orlando', and 'Tampa'.

\begin{tabular}{lll}
\hline Cultivar & \multicolumn{1}{c}{ Maternal parent } & \multicolumn{1}{c}{ Paternal parent } \\
\hline Boca & $($ AMB $\times$ PAP $) \times($ LAP $\times$ PAP $)$ & AMB $\times$ PAP \\
Jax & AMB $\times$ PAP & BRAS \\
Miami & 'Mount Blanc' $\times[($ AMB $\times$ PAP $) \times$ & {$[($ AMB $\times$ PAP $) \times$ BRAS $] \times$ 'Wonderland' } \\
& 'BOUQUET'] & \\
Orlando & $($ AMB $\times$ PAP $) \times$ BRAS & 'Wonderland' \\
Tampa & $($ AMB $\times$ PAP $) \times$ BRAS & 'Wonderland' \\
\hline
\end{tabular}

$\overline{\mathrm{AMB}}=H$. ambiguum $;$ BRAS $=H$. brasilianum $;$ LAP $=H$. lapacense $; \mathrm{PAP}=H$. papilio. Species germplasm used in the breeding originated from the author's research collections; cultivars were 

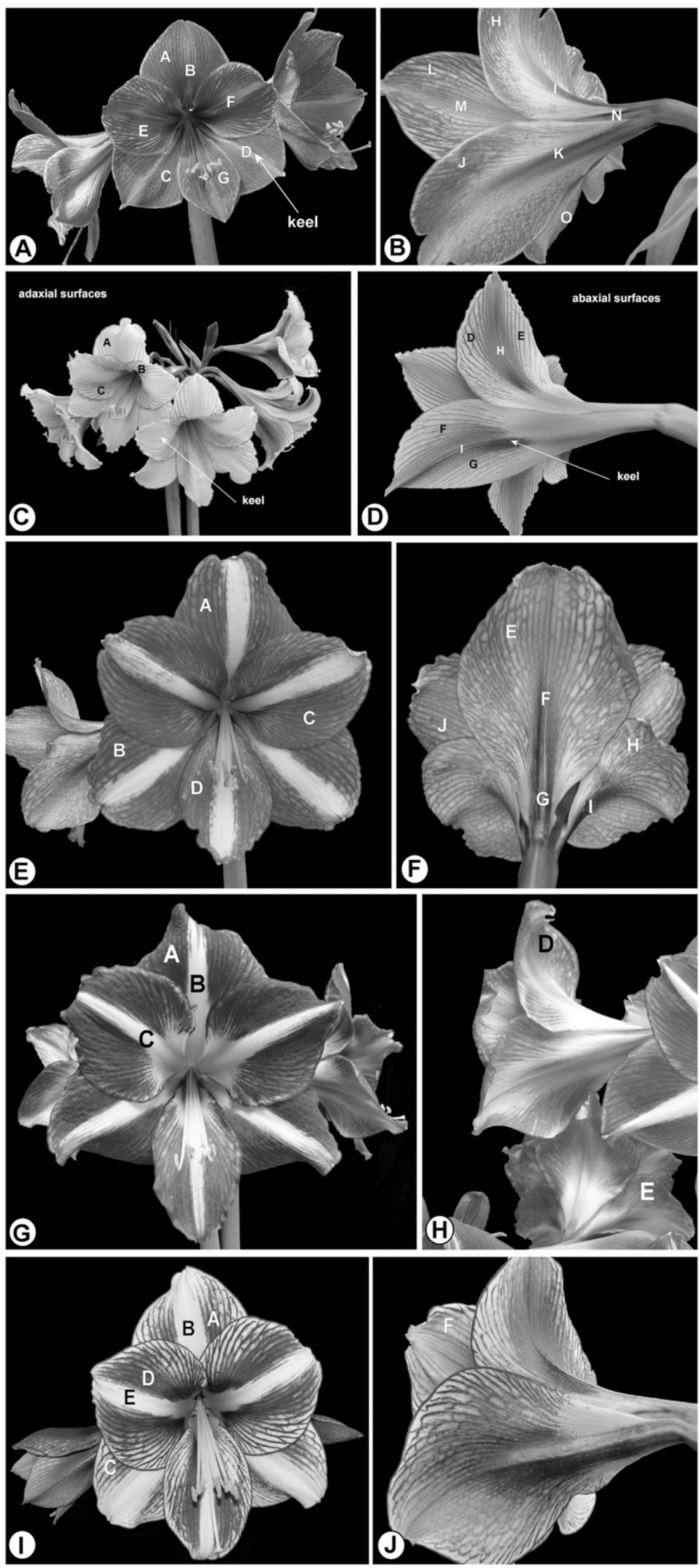

Fig. 1. Pictorial key to flower zones where colorimeter readings were taken on Florida series Hippeastrum cultivars. Letters correspond to zones in Table 2. (A-B) Hippeastrum 'Boca'. (A) Adaxial surfaces. (B) Abaxial surfaces. (C-D) Hippeastrum 'Jax'. (C) Adaxial surfaces. (D) Abaxial surfaces. (E-F) Hippeastrum 'Miami'. (E) Adaxial surfaces. (F) Abaxial surfaces. (G-H) Hippeastrum 'Orlando'. (G) Adaxial surfaces. (H) Abaxial surfaces. (I-J) Hippeastrum 'Tampa'. (I) Adaxial surfaces. (J) Abaxial surfaces. at 2 years of age. Bulbs are 5 to $6 \mathrm{~cm}$ in diameter, increasing to 8 to $11 \mathrm{~cm}$ with age, producing one to two offset bulbs per year. Leaves are lorate with obtuse apices and entire margins, four to six per bulb (seven to 11 late in the season), 60 to $68 \mathrm{~cm}$ long, 3.5 to $4 \mathrm{~cm}$ wide at the base, 5 to $6.5 \mathrm{~cm}$ at the middle, and 3.5 to 4.5 at $5 \mathrm{~cm}$ from the obtuse apex. Young foliage color (upper surface) is RHS yellow-green 144A and the lower surface is RHS yellow-green 144B. Mature foliage upper surface is $L *(C)=37.67, a^{*}(C)=$ $-14.45, b^{*}(C)=19.36$. Mature foliage, lower surface is $\mathrm{L}^{*}(\mathrm{C})=40.46, \mathrm{a} *(\mathrm{C})=$ $-15.16, b^{*}(\mathrm{C})=21.00$. Scapes are 35 to 45 $\mathrm{cm}$ tall, hollow, $\approx 1.5 \mathrm{~cm}$ in diameter, two to three per bulb, bearing four to six flowers each; pedicels are 7.5 to $9.5 \mathrm{~cm}$ long. Flowers are trumpet-shaped, slightly nodding, 15 to $16 \mathrm{~cm}$ long, 12 to $13.5 \mathrm{~cm}$ wide laterally, and 14 to $16 \mathrm{~cm}$ wide dorsal-ventrally. The six tepals are undulate along their margins, of medium texture, appear luminous and crystalline, the adaxial surface lightly striated amethyst (Table 2; closest to RHS red-purple 73A) on a white background, most prominently on the lateral inner tepals, with a picotee of the same color and a green throat. The reverse (abaxial) surface is more deeply colored along the tepal keels, and the tepals are RHS yellow-green 149A in their lower two-thirds. There is no apparent paraperigone. The lateral outer tepals are 13 to $14.5 \mathrm{~cm}$ long, 6 to $6.5 \mathrm{~cm}$ wide at their broadest point; the dorsal outer tepals are 12.5 to $14 \mathrm{~cm}$ long and 6.3 to $6.8 \mathrm{~cm}$ wide; inner lateral tepals are 12.5 to $14 \mathrm{~cm}$ long, 5 to $6 \mathrm{~cm}$ wide, and the ventral inner tepal is 13 to $14.5 \mathrm{~cm}$ long and 4 to $4.7 \mathrm{~cm}$ wide. Stamens are 9.5 to $11 \mathrm{~cm}$ long, RHS white $155 \mathrm{D}$ for most of the length and RHS yellow-green $151 \mathrm{~B}$ in the proximal $5 \mathrm{~cm}$; anthers are elliptic, $\approx 8 \mathrm{~mm}$ long, RHS white $155 \mathrm{~B}$; pollen color is RHS yellow 7A. The style is 13.5 to $14 \mathrm{~cm}$ long, RHS white $155 \mathrm{D}$ for most of length and RHS yellow-green 151B in the proximal $5 \mathrm{~cm}$; the trilobed stigma is $\approx 8 \mathrm{~mm}$ wide. The ellipsoid ovary is 22 to $34 \mathrm{~mm}$ long, 8 to $11.5 \mathrm{~mm}$ wide, RHS green $141 \mathrm{C} ; 2 n=22$ (Fig. 4A).

'Miami'. 'Miami' (Figs. 1E-F and 2E-F) originated as a cross made by the inventor in 2004 as part of a breeding program in Miami, FL (Table 1). First flowering was in Spring 2007 at 3 years of age. Bulbs are 6 to $11 \mathrm{~cm}$ in diameter, producing three to five offsets annually. Leaves are lorate with acute apices and entire margins, four to eight per bulb, RHS green $137 \mathrm{~B}, 50$ to $65 \mathrm{~cm}$ long early in the season, 76 to $82 \mathrm{~cm}$ long late in the season, 3.8 to $4 \mathrm{~cm}$ wide at the base, 5.5 to 6 $\mathrm{cm}$ at midpoint, and 3.5 to $4 \mathrm{~cm}$ wide $5 \mathrm{~cm}$ from the apex. Young foliage, upper surface is RHS yellow-green 144A and lower surface RHS yellow-green 144B. Mature foliage, upper surface is $\mathrm{L}^{*}(\mathrm{C})=39.84, \mathrm{a}^{*}(\mathrm{C})=$ $-16.02, b^{*}(C)=23.02$. Mature foliage, lower surface is: $\mathrm{L} *(\mathrm{C})=46.92, \mathrm{a}^{*}(\mathrm{C})=-16.82$, $b^{*}(C)=26.76$. Individual bulbs produce two to three scapes annually, 45 to $55 \mathrm{~cm}$ tall, 2 to $2.5 \mathrm{~cm}$ in diameter at their midpoint, bearing four flowers per scape; pedicels are 4 to $5.5 \mathrm{~cm}$ 
long. Flowers are broadly funnel-form, 11 to $14 \mathrm{~cm}$ long, 14 to $16 \mathrm{~cm}$ wide laterally and 16 to $17.5 \mathrm{~cm}$ wide dorsal-ventrally composed of six tepals forming a tube in the proximal $2 \mathrm{~cm}$. The broadly ovate lateral outer tepals are 12 to $12.5 \mathrm{~cm}$ long, 7.5 to $8.2 \mathrm{~cm}$ wide; the dorsal outer tepal is 12 to $12.5 \mathrm{~cm}$ long and 8.5 to 9 $\mathrm{cm}$ wide. The outer tepals are broadly ovate, 12.0 to $12.5 \mathrm{~cm}$ long, 7.5 to $8.2 \mathrm{~cm}$ wide, densely striated orange red (about RHS orange-red 33A) on their adaxial surface (Table 2) with a 1.3 - to 1.5 -cm wide median RHS white $155 \mathrm{D}$ keel; the abaxial surface is reticulated orange-red on a white background, the keel is darker and suffused with RHS yellow-green 144C. The lateral inner tepals are ovate, 11.2 to $12 \mathrm{~cm}$ long, and 6.7 to $7 \mathrm{~cm}$ wide. The ventral inner tepal is 12 to $12.2 \mathrm{~cm}$ long and 5 to $5.5 \mathrm{~cm}$ wide. They are colored similarly to the outer whorl, but the dark markings at the throat are more pronounced on laterals. The throat is RHS yellow-green 144B with a paraperigone of lacinate fimbrae. Stamens are 7.8 to $9.4 \mathrm{~cm}$ long, speckled RHS orange-red 33A for their distal half, fading to white and finally RHS yellow-green 151B in the proximal one-third to one-fourth; anthers elliptic, $\approx 7 \mathrm{~mm}$ long, RHS white $155 \mathrm{D}$; pollen is RHS yellow 3C. The style is 10.5 to $11.7 \mathrm{~cm}$ long, diffusely specked RHS red-orange 33A, fading to RHS white $155 \mathrm{D}$ and then RHS yellow-green 151B in its proximal $2 \mathrm{~cm}$; the trilobed stigma is $\approx 6 \mathrm{~mm}$ wide, RHS white 155D (RHS orange-red 33A at margins). The ellipsoid ovary is 20 to $23 \mathrm{~mm}$ long, 8 to $10 \mathrm{~mm}$ wide, and RHS green $141 \mathrm{C} ; 2 n=44$ (Fig. 4A-B).

'Orlando'. 'Orlando' (Figs. 1G-H and $3 \mathrm{~A}-\mathrm{B}$ ) originated as a cross made by the inventor in 2001 as part of a breeding program in Miami, FL (Table 1). First flowering was in Spring 2004 at 3 years of age. Bulbs are 6 to $11 \mathrm{~cm}$ in diameter (19 to $35 \mathrm{~cm}$ circumference), producing three to five offsets annually. Leaves lorate, with acute apices, margins entire, four to six per bulb, up to nine late in the season, 35 to $45 \mathrm{~cm}$ long, lengthening to 65 to $72 \mathrm{~cm}$ late in the season, 3.5 to $4.0 \mathrm{~cm}$ wide at the base, 4.8 to $6.5 \mathrm{~cm}$ wide at the midpoint, and 3.7 to $4.3 \mathrm{~cm}$ wide at $5 \mathrm{~cm}$ from the apex; young foliage colored RHS yellow-green 144A on the upper surface and RHS yellow-green 144B on the lower surface; mature foliage upper surface is: $\mathrm{L}^{*}(\mathrm{C})=37.57, \mathrm{a}^{*}(\mathrm{C})=-13.41, \mathrm{~b}^{*}(\mathrm{C})=$ 18.08 , lower surface is: $\mathrm{L}^{*}(\mathrm{C})=44.34, \mathrm{a}^{*}(\mathrm{C})$ $=-15.71, \mathrm{~b}^{*}(\mathrm{C})=24.09$. Bulbs produce three to four scapes annually, 40 to $65.7 \mathrm{~cm}$ long, $\approx 1 \mathrm{~cm}$ in diameter, each bearing four flowers; pedicels are 5.5 to $8.0 \mathrm{~cm}$ long. Flowers are broadly funnel-form, 13 to 14.5 $\mathrm{cm}$ long, 14 to $16 \mathrm{~cm}$ wide laterally, and 17 to $19 \mathrm{~cm}$ wide dorsal-ventrally. The tepals are fused into a green tube $\mathrm{L}^{*}(\mathrm{C})=57.13, \mathrm{a}^{*}(\mathrm{C})=$ $-13.95, \mathrm{~b} *(\mathrm{C})=32.79$ in the proximal $2 \mathrm{~cm}$. Outer tepals are 12.0 to $12.5 \mathrm{~cm}$ long, 7.9 to $9.0 \mathrm{~cm}$ wide, broadly ovate, with apiculate apices and entire margins, appearing luminous and crystalline. The upper surface is striated RHS red-purple 66A (Table 2), RHS yellow-green $144 \mathrm{C}$ at the base with median
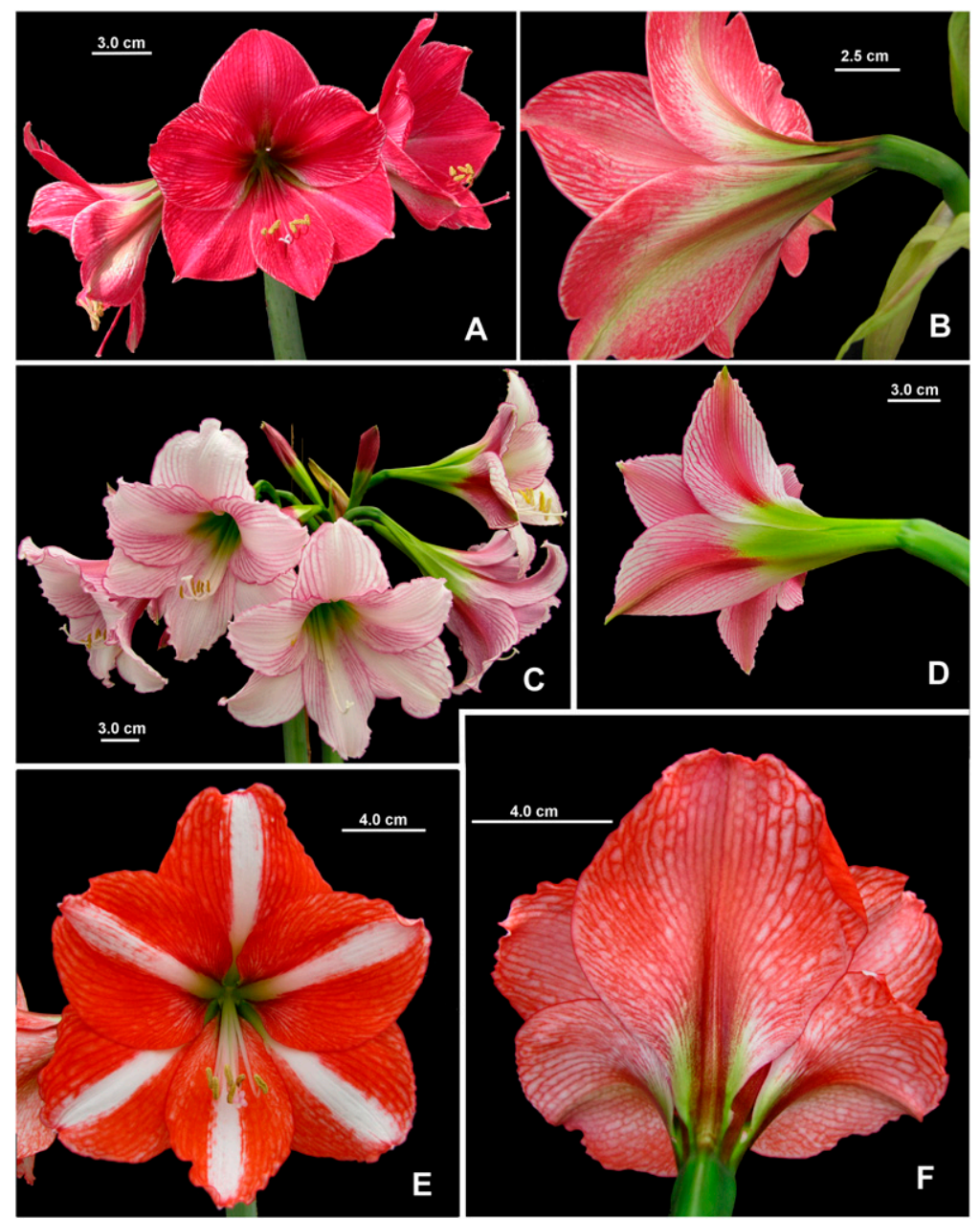

Fig. 2. Hippeastrum 'Boca', 'Jax', and 'Miami'. (A-B) Hippeastrum 'Boca'. (A) Adaxial surfaces. (B) Abaxial surfaces. (C-D) Hippeastrum 'Jax'. (C) Adaxial surfaces. (D) Abaxial surfaces. (E-F) Hippeastrum 'Miami'. (E) Adaxial surfaces. (F) Abaxial surfaces.
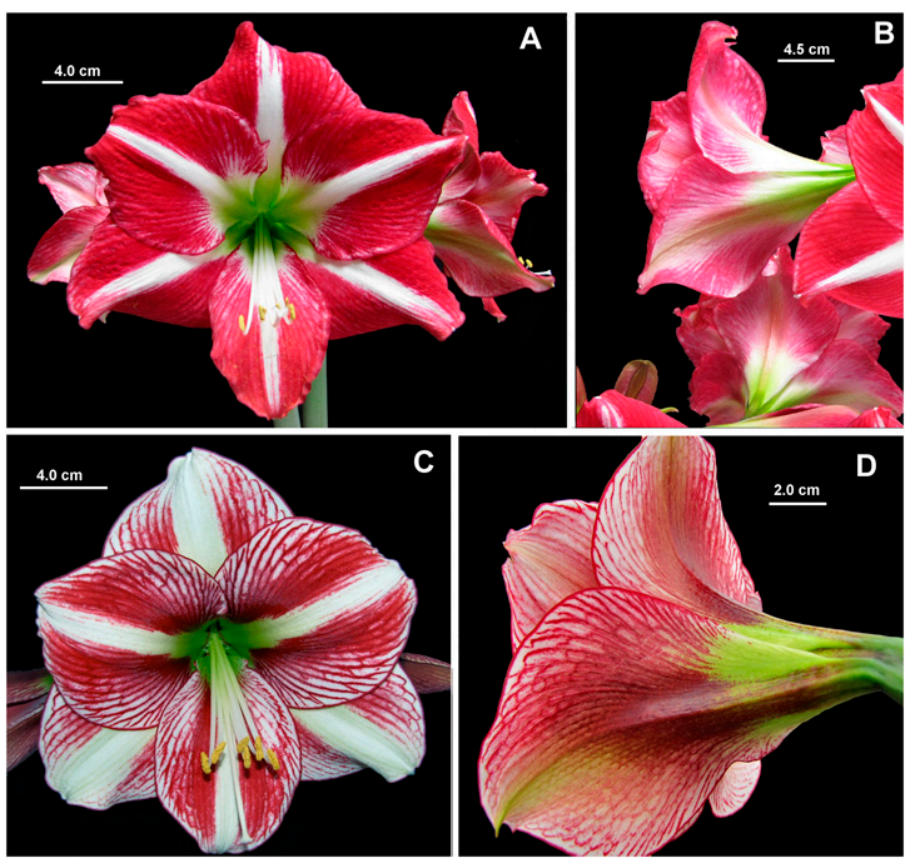

Fig. 3. Hippeastrum 'Orlando' and 'Tampa'. (A-B) Hippeastrum 'Orlando'. (A) Adaxial surfaces. (B) Abaxial surfaces. (C-D) Hippeastrum 'Tampa'. (C) Adaxial surfaces. (D) Abaxial surfaces. 
Table 2. Colorimeter readings under the CIELAB color space for various locations on the flowers of Florida series Hippeastrum hybrid. ${ }^{z}$

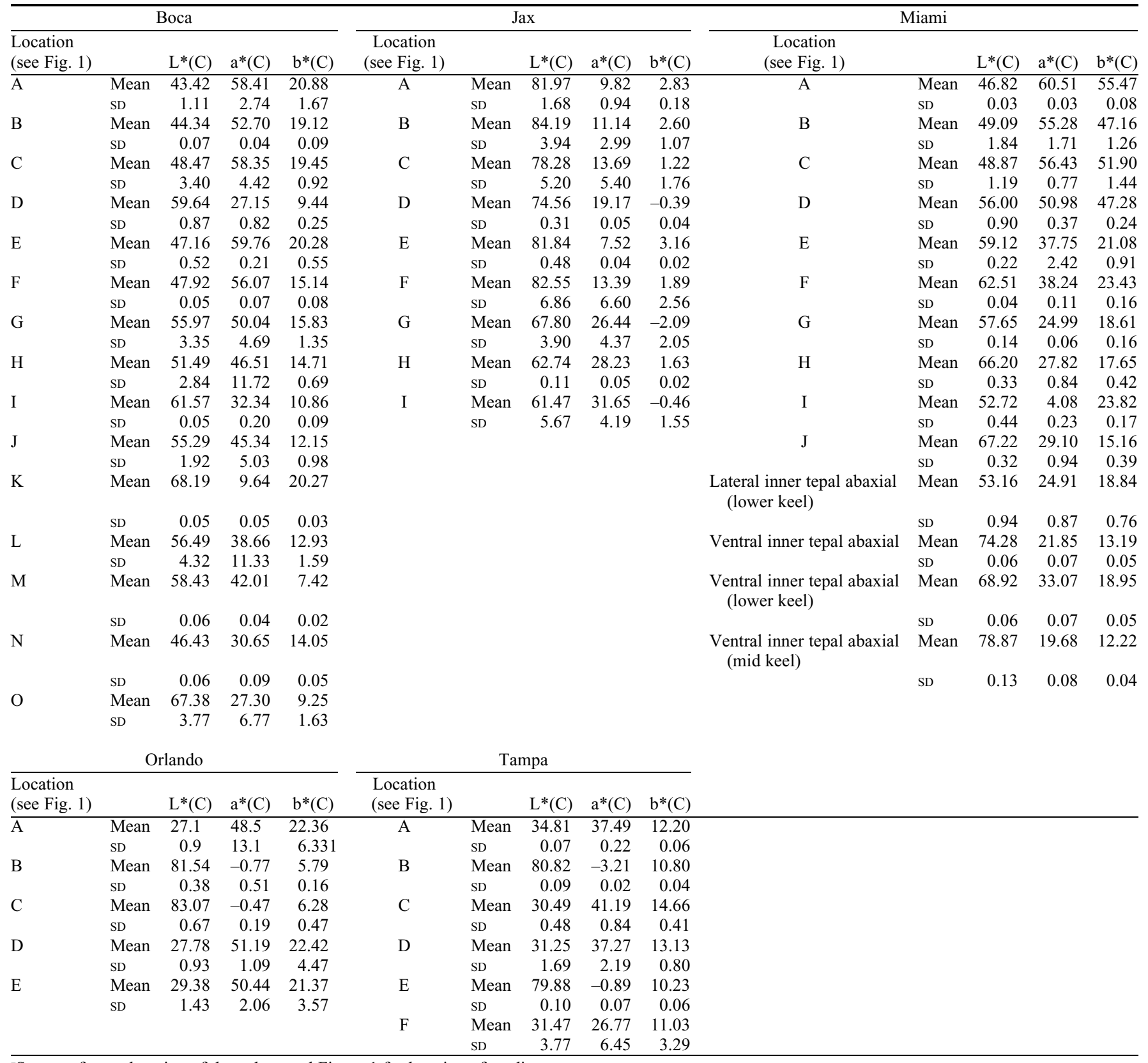

${ }^{\mathrm{z}}$ See text for explanation of the values and Figure 1 for location of readings.

RHS white $155 \mathrm{D}$ keels 1.3 to $1.5 \mathrm{~cm}$ wide; lower surface striations are more diffuse with a RHS white $155 \mathrm{D}$ background and toward the middle, RHS yellow-green $144 \mathrm{C}$ toward the base, keel suffused with RHS yellowgreen $144 \mathrm{C}$ near apex and on either side in the lower half. Inner whorl was ovate and the ventral narrower; inner laterals are 11.5 to $12.0 \mathrm{~cm}$, the ventral 4.8 to $5.0 \mathrm{~cm}$, apex apiculate, margin entire, and colored as per the outer whorl; the throat is green with a paraperigone of short, lacinate fimbrae. Stamens are 8.9 to $10.0 \mathrm{~cm}$ long, RHS white $155 \mathrm{D}$ for most of their length, RHS yellowgreen $144 \mathrm{C}$ in the proximal one-fourth; anthers are elliptic, $\approx 7 \mathrm{~mm}$ long, RHS white $155 \mathrm{D}$; pollen is RHS yellow $3 \mathrm{D}$. The style is 11.5 to $12.0 \mathrm{~cm}$ long, RHS white $155 \mathrm{D}$ for most of its length with faint RHS purple-red
66A speckling below the stigma and RHS yellow-green $144 \mathrm{C}$ in the proximal one-fourth; stigma is trilobed, RHS white 155D, 6 to $7 \mathrm{~mm}$ wide. The ellipsoid ovary is 21 to $24 \mathrm{~mm}$ long, 8 to $10 \mathrm{~mm}$ wide, RHS green $141 \mathrm{C}$. The fruit is a loculicidal capsule, $\approx 2 \mathrm{~cm}$ long, $\approx 3 \mathrm{~cm}$ wide, papery at dehiscence; seed flattened, obliquely winged, RHS brown $200 \mathrm{~A}, \approx 1 \mathrm{~cm}$ long, $5 \mathrm{~mm}$ wide; $2 n=43$ (4n-1; Figs. 4A and 4C).

'Tampa'. 'Tampa' (Figs. 1I-J and 2C-D) originated as a cross made by the inventor in 2004 as part of a breeding program in Miami, FL. The cultivar flowered for the first time in Spring 2007 at 3 years of age. Bulbs are 6.0 to $9.7 \mathrm{~cm}$ in diameter (19 to $30 \mathrm{~cm}$ circumference), producing three to five offsets annually. Leaves are lorate, six to eight per bulb, up to 12 late in the season, 45 to $55 \mathrm{~cm}$ long, lengthening to 68 to $73 \mathrm{~cm}$ late in the season, 4.2 to $4.7 \mathrm{~cm}$ wide at the base, 6.5 to $7.1 \mathrm{~cm}$ wide at the midpoint, and 4.0 to $4.3 \mathrm{~cm}$ wide 5 $\mathrm{cm}$ from the acute apex; young foliage, upper surface is: RHS yellow-green 144A, and lower surface is: RHS yellow-green 144B; mature foliage, upper surface is: $\mathrm{L}^{*}(\mathrm{C})=37.60$, $a^{*}(C)=-13.14, b^{*}(C)=17.66$. Mature foliage, lower surface is: $\mathrm{L}^{*}(\mathrm{C})=43.40, \mathrm{a}^{*}(\mathrm{C})=$ $-15.16, b^{*}(\mathrm{C})=22.94$. Bulbs produce two to three scapes annually, 31 to $48 \mathrm{~cm}$ long, $1 \mathrm{~cm}$ in diameter, each bearing four to six flowers; pedicels are 5 to $9.5 \mathrm{~cm}$ long. Flowers are broadly funnel-form, 13 to $17 \mathrm{~cm}$ long, 13 to $14 \mathrm{~cm}$ wide laterally, and 16 to $17 \mathrm{~cm}$ wide dorsal-ventrally, the six tepals fused and forming a tube in the proximal $2 \mathrm{~cm}$, green: $\mathrm{L}^{*}(\mathrm{C})=57.18, \mathrm{a}^{*}(\mathrm{C})=-14.00, \mathrm{~b}^{*}(\mathrm{C})=$ 33.41. The broadly ovate outer tepals are 

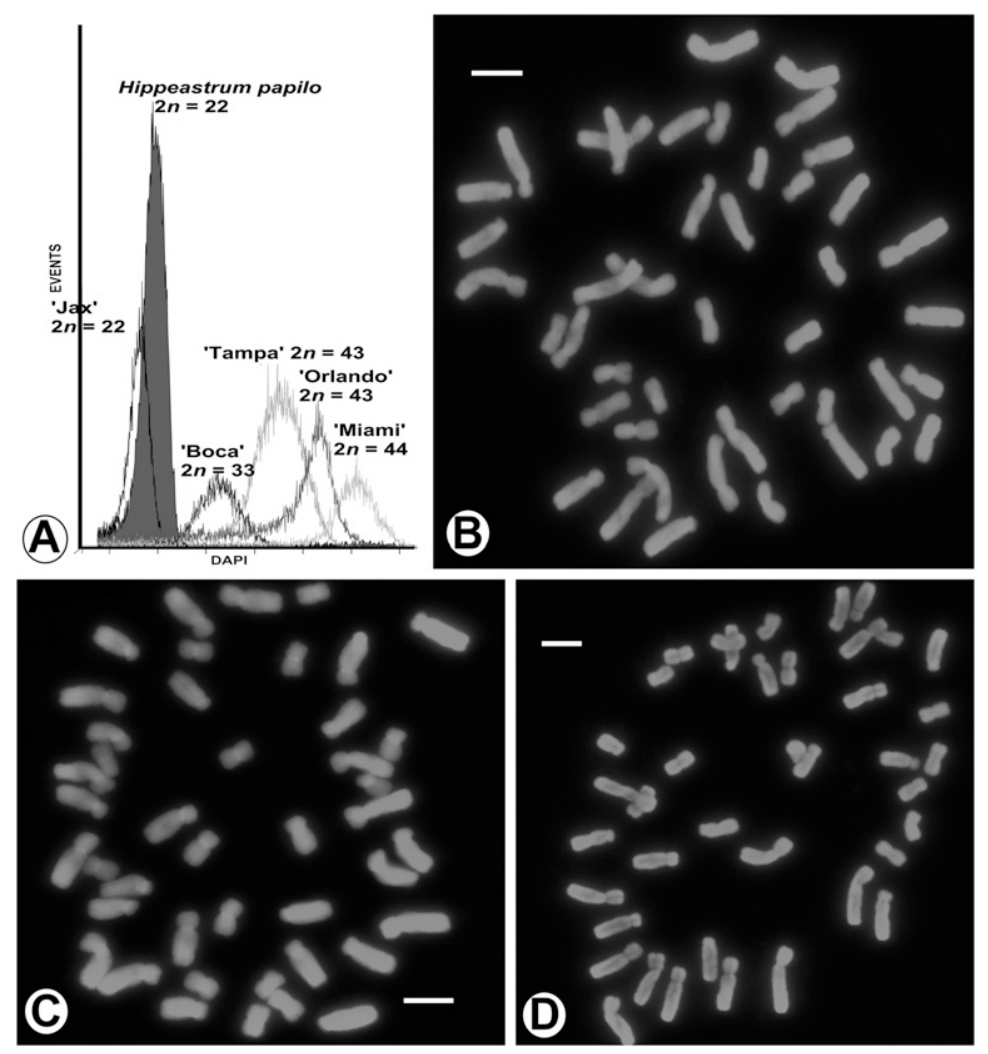

Fig. 4. Flow cytometric comparison of ploidy in five Hippeastrum cultivars and mitotic metaphase chromosome preparations. (A) Composite flow cytometric peaks of five Hippeastrum cultivars with $\mathrm{H}$. papilio used as standard. (B) $2 n=44$ chromosomes of Hippeastrum 'Miami'. C. $2 n=43$ chromosomes of Hippeastrum 'Orlando'. $2 n=43$ chromosomes of Hippeastrum 'Tampa'. Scale $=10 \mu \mathrm{m}$.

Table 3. Flowering performance of Hippeastrum 'Boca', 'Jax', 'Miami', 'Orlando', and 'Tampa' under ambient south Florida conditions over 5 years. $^{2}$

\begin{tabular}{|c|c|c|c|c|}
\hline Cultivar & $\mathrm{Yr}$ & No. & Mean no. scapes per bulb (sD) & Mean no. flowers per scape (SD) \\
\hline \multirow[t]{5}{*}{ Boca } & 2009 & 5 & $2.5( \pm 0.5)$ & $3.4( \pm 0.5)$ \\
\hline & 2010 & 8 & $2.7( \pm 0.5)$ & $3.6( \pm 0.4)$ \\
\hline & 2011 & 11 & $2.2( \pm 0.6)$ & $3.7( \pm 0.3)$ \\
\hline & 2012 & 13 & $1.9( \pm 0.7)$ & $3.7(+0.4)$ \\
\hline & 2013 & 16 & $2.8( \pm 0.6)$ & $3.8( \pm 0.2)$ \\
\hline \multirow[t]{5}{*}{ Jax } & 2009 & 4 & $2.7( \pm 0.5)$ & $4.2( \pm 0.9)$ \\
\hline & 2010 & 6 & $3.1( \pm 0.8)$ & $4.1( \pm 0.8)$ \\
\hline & 2011 & 9 & $2.3( \pm 0.7)$ & $4.3( \pm 0.7)$ \\
\hline & 2012 & 11 & $2.1( \pm 0.6)$ & $4.3( \pm 0.6)$ \\
\hline & 2013 & 14 & $2.9( \pm 0.7)$ & $4.2( \pm 0.8)$ \\
\hline \multirow[t]{5}{*}{ Miami } & 2009 & 6 & $3.0( \pm 0.4)$ & $3.6( \pm 0.4)$ \\
\hline & 2010 & 10 & $3.1( \pm 0.5)$ & $3.3( \pm 0.6)$ \\
\hline & 2011 & 14 & $2.6( \pm 0.7)$ & $3.4( \pm 0.3)$ \\
\hline & 2012 & 18 & $2.4( \pm 0.8)$ & $3.4( \pm 0.4)$ \\
\hline & 2013 & 21 & $3.1( \pm 0.6)$ & $3.6( \pm 0.3)$ \\
\hline \multirow[t]{5}{*}{ Orlando } & 2009 & 8 & $3.3( \pm 0.7)$ & $3.7( \pm 0.2)$ \\
\hline & 2010 & 12 & $3.2( \pm 0.7)$ & $3.9( \pm 0.3)$ \\
\hline & 2011 & 15 & $3.1( \pm 0.6)$ & $3.6( \pm 0.4)$ \\
\hline & 2012 & 18 & $3.1( \pm 0.5)$ & $3.8( \pm 0.3)$ \\
\hline & 2013 & 24 & $3.2( \pm 0.6)$ & $3.9( \pm 0.2)$ \\
\hline \multirow[t]{5}{*}{ Tampa } & 2009 & 5 & $2.6( \pm 0.65$ & $4.0( \pm 0.3)$ \\
\hline & 2010 & 8 & $3.0( \pm 0.8)$ & $3.9( \pm 0.2)$ \\
\hline & 2011 & 11 & $2.8( \pm 0.6)$ & $4.1( \pm 0.1)$ \\
\hline & 2012 & 14 & $2.8( \pm 0.6)$ & $3.8( \pm 0.3)$ \\
\hline & 2013 & 16 & $2.9( \pm 0.5)$ & $4.2( \pm 0.2)$ \\
\hline
\end{tabular}

$\overline{{ }^{\mathrm{z}} \text { Bulbs were at least } 5.0 \mathrm{~cm} \text { in diameter and at least } 4 \text { years old. Bulbs used in these tests were propagated }}$ strictly by division.

12.0 to $12.5 \mathrm{~cm}$ long, 7.5 to $8.0 \mathrm{~cm}$ wide, with an apiculate apex, appearing luminous and crystalline, striated RHS red-purple 60A (Table 2) on their adaxial surface, most intensely on the laterals and most densely toward the keel, RHS yellow-green $144 \mathrm{C}$ at the base, with median RHS white 155D keels 1.3 to $1.5 \mathrm{~cm}$ wide and a picotee of RHS red-purple 60A; lower surface striations are more diffuse with a RHS white $155 \mathrm{D}$ back- ground, RHS yellow-green $144 \mathrm{C}$ toward the base, keel darker, and suffused with RHS yellow-green $144 \mathrm{C}$ near the apex and on either side in the lower half; the throat is RHS yellow-green $144 \mathrm{C}$ with a paraperigone of short lacinate fimbrae and a narrow RHS red-purple 59B margin. The lateral inner tepals are 11.0 to $11.5 \mathrm{~cm}$ long and 7.4 to 7.8 $\mathrm{cm}$ wide; the ventral inner tepal is 11.5 to $12.0 \mathrm{~cm}$ long and 6.0 to $6.5 \mathrm{~cm}$ wide; both surfaces are colored as per the outer whorl. Stamens are 8.0 to $9.0 \mathrm{~cm}$ long, the filaments RHS white $155 \mathrm{D}$ in their distal two-thirds, and RHS yellow-green $144 \mathrm{C}$ in their proximal one-third; anthers are ellipsoid, $\approx 7 \mathrm{~mm}$ long, RHS white 155D; pollen RHS yellow 6C. The style is 11.5 to $12.0 \mathrm{~cm}$ long, RHS white $155 \mathrm{D}$ for most of its length, green at the base; the trilobed stigma is $\approx 7 \mathrm{~mm}$ wide. The ellipsoid ovary is 23.8 to $30.2 \mathrm{~mm}$ long, 9.9 to $11.5 \mathrm{~mm}$ wide, RHS green $141 \mathrm{C} ; 2 n=$ 43 (4n-1; Figs. 4A and 4D).

\section{Performance}

The cultivars have flowered regularly for at least 5 years under ambient south Florida conditions (Table 3). Bulbs are dried in their containers in late October and maintained under $60 \%$ shade in pots without irrigation until February. They are then transplanted into fresh substrate and lightly irrigated every 3 to $5 \mathrm{~d}$ until scape emergence, after which irrigation was provided every third day. First scapes emerged from the bulbs 1 to 3 weeks after irrigation started. The first flowers opened 3 to 4 weeks after the scapes first emerged. Under these conditions, they are regularly exposed in summer to daytime temperatures greater than $32{ }^{\circ} \mathrm{C}$ and night minimums as high as $27^{\circ} \mathrm{C}$.

Bulbs have also flowered when forced according to protocols established by Okubo (1993). Bulbs were placed in darkness at $13{ }^{\circ} \mathrm{C}$ and $80 \%$ relative humidity (RH) for 8 weeks without irrigation, then grown at $25^{\circ} \mathrm{C}$, $70 \% \mathrm{RH}$, with $13 \mathrm{~h}$ of light [photosynthetic photon flux $(P P F)=800 \mathrm{umol} \cdot \mathrm{m}^{-2} \cdot \mathrm{s}^{-1}$ and irrigation on alternate days (Table 4). All five cvs. have been experimentally and successfully propagated using twin scale cuttage (Table 5; Traub, 1958) on bulbs $\approx 5.0 \mathrm{~cm}$ in diameter. All five cultivars flowered 2.5 years after twin scaling was started.

\section{Cultural Notes}

These five cultivars require well-drained organic substrate with a $\mathrm{pH}$ of 6.0 to 6.5 . In the breeding program, a 5:4:1 mix was used of aged pine bark:coconut coir dust:coarse sand, modified subsequently to $25 \%$ total volume with coarse perlite. It was amended with $5.0 \mathrm{~kg} \cdot \mathrm{m}^{-3} 17 \mathrm{~N}-2.3 \mathrm{P}-10 \mathrm{~K}$ Floricote (Florikan, Sarasota, FL), $4.2 \mathrm{~kg} \cdot \mathrm{m}^{-3}$ dolomite and $1.2 \mathrm{~kg} \cdot \mathrm{m}^{-3}$ Micromax (Scott's, Milpitas, CA). Bulbs were grown in 2.7- to 5.4-L containers, depending on size, on benches under $50 \%$ Saran shade (maximum $P P F=$ $1000 \mathrm{umol} \cdot \mathrm{m}^{-2} \cdot \mathrm{s}^{-1}$ ) and irrigated as needed. 
Table 4. Flowering performance of Hippeastrum 'Boca', 'Jax', 'Miami', 'Orlando', and 'Tampa' treated according to the forcing protocols of Okubo (1993).

\begin{tabular}{|c|c|c|c|c|c|c|}
\hline Cultivar & $\mathrm{Yr}^{\mathrm{z}}$ & No. & $\begin{array}{l}\text { Mean no. of scapes } \\
\text { per bulb (SD) }\end{array}$ & $\begin{array}{l}\text { Mean no. of flowers } \\
\text { per scape (SD) }\end{array}$ & $\begin{array}{c}\text { Mean days to emergence of first } \\
\text { scape after treatment (SD) }\end{array}$ & $\begin{array}{l}\text { Mean days to anthesis of first } \\
\text { scape after treatment (SD) }\end{array}$ \\
\hline \multirow[t]{2}{*}{$\overline{\text { Boca }}$} & 2012 & 4 & $2.0( \pm 0.0)$ & $3.7( \pm 0.5)$ & $23.8( \pm 2.2)$ & $41.5( \pm 1.3)$ \\
\hline & 2013 & 8 & $2.1( \pm 0.4)$ & $3.7( \pm 0.5)$ & $23.3( \pm 1.8)$ & $42.3( \pm 1.0)$ \\
\hline \multirow[t]{2}{*}{ Jax } & 2012 & 4 & $2.3( \pm 0.5)$ & $4.2( \pm 0.4)$ & $21.0( \pm 1.6)$ & $39.3( \pm 1.0)$ \\
\hline & 2013 & 8 & $2.4( \pm 0.5)$ & $4.1( \pm 0.5)$ & $20.6( \pm 1.4)$ & $39.6( \pm 1.1)$ \\
\hline \multirow[t]{2}{*}{ Miami } & 2012 & 4 & $2.3( \pm 0.5)$ & $3.8( \pm 0.5)$ & $23.0( \pm 1.4)$ & $43.3( \pm 0.5)$ \\
\hline & 2013 & 8 & $2.3( \pm 0.5)$ & $3.8( \pm 0.5)$ & $23.4( \pm 1.1)$ & $43.3( \pm 1.0)$ \\
\hline \multirow[t]{2}{*}{ Orlando } & 2012 & 4 & $2.5( \pm 0.6)$ & $3.6( \pm 0.6)$ & $19.5( \pm 1.3)$ & $40.0( \pm 0.8)$ \\
\hline & 2013 & 8 & $2.3( \pm 0.5)$ & $3.9( \pm 0.5)$ & $20.0( \pm 1.3)$ & $40.5( \pm 0.9)$ \\
\hline \multirow[t]{2}{*}{ Tampa } & 2012 & 4 & $2.3( \pm 0.5)$ & $4.0( \pm 0.5)$ & $21.5( \pm 1.3)$ & $43.0( \pm 0.8)$ \\
\hline & 2013 & 8 & $2.4( \pm 0.5)$ & $3.9( \pm 0.6)$ & $22.0( \pm 1.1)$ & $43.4( \pm 0.9)$ \\
\hline
\end{tabular}

${ }^{\mathrm{z} F o r c i n g}$ pretreatment began 15 Sept. and lasted for 8 weeks, consisting of dark storage in dry medium at $13{ }^{\circ} \mathrm{C}$ and $70 \%$ relative humidity.

Table 5. Propagation of Hippeastrum 'Boca', 'Jax', 'Miami', 'Orlando', and 'Tampa' from twin scale cuttings in 2011.

\begin{tabular}{|c|c|c|c|c|c|}
\hline Cultivar & Date cuttings taken & No. & $\begin{array}{l}\text { Mean no. days } \\
\text { until bulblet formation (SD) }\end{array}$ & $\begin{array}{l}\text { Percent scales } \\
\text { forming bulblets }\end{array}$ & $\begin{array}{l}\text { Mean no. bulblets } \\
\text { per cutting }{ }^{\mathrm{y}}(\mathrm{SD})\end{array}$ \\
\hline$\overline{\text { Boca }}$ & 15 Sept. 2011 & 38 & $42.7( \pm 4.9)$ & 75 & $1.2(0.3)$ \\
\hline Jax & 10 Sept. 2011 & 43 & $38.3( \pm 3.8)$ & 81 & $1.1(0.3)$ \\
\hline Miami & 15 Oct. 2011 & 40 & $47.5( \pm 3.4)$ & 72 & $1.2(0.2)$ \\
\hline Orlando & 13 Oct. 2011 & 36 & $40.2( \pm 5.1)$ & 84 & $1.3(0.2)$ \\
\hline Tampa & 19 Feb. 2011 & 35 & $51.6( \pm 4.2)$ & 78 & $1.1(0.4)$ \\
\hline
\end{tabular}

${ }^{\mathrm{z}}$ Bulbs used for cuttage were $\approx 5.0 \mathrm{~cm}$ in diameter.

${ }^{y}$ Successful cuttings only.

Pest problems have included mealybug (Pseudococcus Westwood spp.), scales [Florida wax scale, Ceroplastes floridensis Comstock; Magnolia white scale, Pseudaulacapsis cockerelli (Cooley)], and Stethobaris nemesis Prena and O'Brien, an introduced baridinid weevil known as amaryllis weevil (Epsky et al., 2008; Prena and O'Brien, 2011), which can be particularly destructive if unchecked. Bulbs in active growth, especially those grown outdoors or in open structures, should be inspected periodically for grasshoppers [(Romalaea guttata (Latreille)], which can defoliate the plants. To date, these cultivars have not yet exhibited foliar mottling symptomatic of Hippeastrum mosaic virus. The cultivars are not highly susceptible to foliar infection by Staganospora curtisii (red scorch).

\section{Availability}

All five cultivars have patent applications filed with the U.S. Patent Office, and licensing will be handled by the USDA-ARS Office of Technology Transfer (<http://www.ars. usda.gov/business/docs.htm?docid $=763 \&$ page $=5>$ ). For technical questions, please contact the author (alan.meerow@ars.usda. gov). For licensing information, please contact June Blalock, Technology Licensing Program Coordinator (june.blalock@ars.usda.gov).

\section{Literature Cited}

Ayala-Silva, T. and A.W. Meerow. 2006. Evaluation of flower color using a Colorimeter and the Royal Horticultural Society Charts. Proc. Intl. Trop. Hort. Soc. 50:138-144.

Ayala-Silva, T., R.J. Schnell, A.W. Meerow, M. Winterstein, C. Cervantes, and J.S. Brown. 2005. Determination of color and fruit traits of half-sib families of mango (Mangifera indica L.). Proc. Fla. State Hort. Soc. 118:253-257.

Bell, W.D. 1973a. New potentials in amaryllis breeding. Proc. Florida State Hort. Soc. 86:462-466.

Bell, W.D. 1973b. The role of triploids in amaryllis hybridization. Plant Life 29:59-61.

Bell, W.D. 1977. More potentials in amaryllis breeding. Plant Life 33:65-69.

Epsky, N.D., T.J. Weissling, A. Walker, A.W. Meerow, and R.H. Heath. 2008. Life history and damage of a new Baradinae weevil (Coleoptera: Curculionidae) on amaryllis. Fla. Entomol. 91:214-219.

Gonnet, J.F. 1993. CIELAB measurement, a precise communication in flower colour: An example with carnation (Dianthus caryophyllus) cultivars. J. Hort. Sci. 68:499-510.

Gonnet, J.F. 1998. Colour effects of copigmentation of anthocyanins revisited. 1: A colorimetric definition using the CIELAB scale. Food Chem. 63:409-415.

Meerow, A.W. 2009. Tilting at windmills: 20 years of Hippeastrum breeding. Isr. J. Plant Sci. 57:303-313.

Meerow, A.W. and T. Ayala-Silva. 2008. 'Miami Sunrise', 'Miami Sunset', 'Tangelo': Three cultivars of Tecoma guarume. HortScience 43:546-548.

Okubo, H. 1993. Hippeastrum (Amaryllis), p. 321334. In: DeHertogh, A.A. and M. LeNard (eds.). The physiology of flower bulbs. Elsevier, Amsterdam, The Netherlands.

Prena, J. and C.W. O'Brien. 2011. Five new species of the Stethobaris Leconte complex (Coleoptera: Curculionidae: Baridinae) associated with Amaryllidaceae. Proc. Entomol. Soc. Wash. 113:163-184.

Royal Horticultural Society. 1995. RHS colour chart. 3rd Ed. Royal Hort. Soc., London, UK.

Traub, H.P. 1958. The amaryllis manual. Macmillan, New York, NY.

Trotter, J. 2004. WinMDI (Windows Multiple Document Interface for Flow Cytometry). Version 2.8. The Scripps Institute, Flow Cytometry Core Facility. 4 Aug. 2014. <http:// facs.scripps.edu/software.html>. 